\title{
The Needs and Services of Elderly Women Based on Kinship in Indonesia: A Qualitative Study
}

\author{
Setyowati Brotosudirdjo \\ Faculty of Nursing, Universitas Indonesia, Depok, West Java, Indonesia
}

Email address:

wati123@ui.ac.id

\section{To cite this article:}

Setyowati Brotosudirdjo. The Needs and Services of Elderly Women Based on Kinship in Indonesia: A Qualitative Study. American Journal of Nursing Science. Vol. 6, No. 3, 2017, pp. 141-145. doi: 10.11648/j.ajns.20170603.11

Received: November 28, 2016; Accepted: February 8, 2017; Published: March 6, 2017

\begin{abstract}
The improvement of the health care system has the impact of increasing the population of the elderly in Indonesia. Even though Indonesia still has a small percentage of elderly, slowly but surely this population will increase. The population of the elderly in Indonesia was approximately 18.4 million in 2005, and is expect to increase to 32 million in 2020 or $12 \%$ of the total population $[1,16]$. Within that population, the percentage of elderly women is greater than that for men. and the life expectancy of women is also higher than men. This research study aims to explore the need for services amongst elderly Indonesians especially women that are based on Indonesian ethnic culture. A qualitative study with focus group discussions involved six elderly women and their families. Literature review and observations have been performed in the different ethnic groups. The result has shown that the elderly are not provided with the proper services and respect, as was formerly the case, especially in the eastern region. They face a range of problems ranging from physical and psychological to social, spiritual and economical. Especially amongst women, they have specific needs as most of the elderly women stay at home and tend to spend their time on spiritual activities such as praying rather than physical and social activities because there is no service provision to ensure their safety and satisfaction. This study recommends that women elderly in Indonesia need more services from their families, government and community based on their values and culture. All parties have to aware of this situation and use the results of this study as a basic template for further appropriate intervention and research.
\end{abstract}

Keywords: Indonesian Elderly Services, The Needs of Elderly Women, Social and Cultural Values

\section{Introduction}

The improvement of the health care system will improve societal growth and development and reduce birth rates. This in turn will increase the population of the elderly. In addition to increasing the elderly population, it also affects changes in the socio-cultural values of the nation. In this particular case the notion that the elderly are traditionally cared for by their children, but due to busy lifestyles the children put their parents into care homes. In Indonesia most of the elderly stay at home and tend to spend their time on spiritual activities such as praying, rather than physical and social activities because there are no specific facilities to ensure their safety and satisfaction. Most of the Indonesian elderly live with their children, few live alone. The Indonesian government has prepared various programs for elderly services. The Indonesian government provides only a few of nursing homes (Pantiwreda) for the elderly (mostly in the cities) with very limited services. However, especially amongst women elderly, there are specific needs which need to be recognized and provided for. Research done by Sri Iswanti, et-al (2010) has shown that there is some abuse amongst elderly women [16]. The abuse includes physical abuse, physical isolation by being locked in the house, or social isolation where they are not allowed to communicate with their friends and family. This abusive behavior is displayed by their husbands, children, grandchildren and in-laws. The factors which propagate the abuse behavior are misunderstanding between the family, the family being too busy to look after the elderly, no communication, disrespectful behavior, feelings of shame, actions of revenge for past misdeeds and mostly also about the inheritance. The impact of abusive behavior can result in poor physical and psychological health amongst women and cause negative feelings such as upset, depression and suicide. For that reason, researchers need to know more about the specific needs and expectations of elderly women and be better able to tailor government services, their family's approach and the community's caring attitude. 


\section{The Purpose of the Study}

This research study aims to explore the need for better healthcare and recreational services especially among elderly Indonesian women which are based on Indonesian ethnic culture.

\section{Literature Review}

The most important cultural influence on elderly care services in Indonesia is the tradition that most elderly live with their children, only a few of them live alone. The culture in Indonesian society implies that it is inappropriate for the children to leave their elderly parents to stay alone. It emphasizes how important it is for family to look after their parents to maintain their quality of life. The population of the elderly in Indonesia was approximately 18.4 million in 2005 , and is expected to increase to 32 million in 2020 or $12 \%$ of the total population. Elderly women outnumber men within that segment of the population $[13,14]$. In fact, the life expectancy of women is higher than men. In 1998 the life expectancy of Indonesian women was 66 while for men it was $62,[5,6,14]$. This is attributed to biological differences such as the lower risk of cardiovascular diseases among women and due to the culture reason that men face higher physical risks during their working lives.

Problems faced by the elderly in Indonesia include: poverty, malnutrition, poor health, and difficult access to social and health services. There are particular difficulties in remote areas for example: lack of transportation facilities, lack of health facilities and infrastructure, lack of communication facilities, and the high cost of medical care [9 $13,14]$. Most of the Indonesian elderly stay at home and tend to spend their time on spiritual activities such as praying rather than physical and social activities. There are no specific facilities or programs to ensure their safety and meet their needs.

\section{Elderly Womens' Health}

There are two important events in a woman's life namely: the puberty period marking the beginning of menstruation that is called 'menarche' and the menopause when the menstruation stops and is followed by the 'climacterium' period. Menopause is biological statement marking the end of a menarche period of a woman. It usually happens above 40 years of age. During the transition period, the ovary becomes weak and their sexual drive decreases naturally. These hormonal changes influence physical and psychological well-being, and manifest themselves as clinically identifiable symptoms for example: spontaneous sensations of warmth, usually felt on the chest, neck and face, and often accompanied by perspiration, palpitations, and anxiety. These episodes are commonly described as 'hot flushes' and night sweats. Consequently the elderly have emotional problems, they become very emotionally sensitive. In particular, the decrease in sexual drive in elderly women influences the sexual life of the couple. In some cases, this can be a trigger for abuse of elderly women.

\section{Methodology}

The study has been performed using qualitative methods with focus group discussions involving six elderly women and their families. The participants were chosen via a purposive sampling method, with the main criteria that the elderly women live in the Depok area and wanted to voluntarily participate in the study. The observation of the elderly services and also the literature review were done with special consideration of the regulations governing elderly services in the Depok area, West Java. Ethical approval was obtained by the Faculty of Nursing, University of Indonesia Ethics Committee. The participants' recruitment was started by the Researcher among elderly women who visited the Health Care Center Cisalak, Depok. The Researcher asked the participants to provide informed consent after providing background information and explaining the rationale of the study. The FGD (Focused group discussion) was done with six participants only since they already fulfilled the study criteria and saturation was achieved., It was noted that it was difficult to recruit participants due to reservations from the families. The focus group method has traditionally been used to validate data obtained in research [12], because interviewing focus groups allows interaction between participants and the generation and confirmation of ideas and motivations. It is hoped that the focus group sessions create a relaxed forum with peer support for the participants. The researcher can examine responses for clarity, pinpointing areas of agreement and disagreement. The researcher reinforces the notion that all opinions will be respected and that truthful and forthright responses are important to understanding individual perceptions [10, 11]. Evaluative focus group assessment can be used to identify barriers to behavioral change, determine strategies for future interventions, and identify beliefs regarding existing health promotion programs [8]. A 50-minute focus group session ensued which was recorded and later transcribed verbatim for data analysis. Data was analyzed by thematic context analysis strategy based on the context of: Physical, psychological, social, economic and spiritual needs. Data from the focus groups were reviewed to capture viewpoints and identify common themes. The transcripts were thoroughly read line-by-line by researchers who listened to the audio recordings. Key sentences and concepts were highlighted and coded. Initial themes were identified and grouped. Re-reading was then completed with themes added, deleted, and merged. Main themes were developed and reviewed by the Researcher. 


\section{Results}

\section{The Characteristics of Participants}

Table 1. The Characteristics of participants in Depok, West Java, Indonesia, 2015.

\begin{tabular}{llllll}
\hline Participant & Age & Education & Marital status & Children & Job \\
\hline P1 & 61 & Masters Degree & Married 35 y & 2 children & Retired /Oil company \\
P2 & 58 & Senior High School & Widower & No children & Sales' shop \\
P3 & 60 & Bachelor of Science Degree & Married 36y & 2 children & Retired \\
P4 & 63 & Senior High School & Widower & 1 child & Pension from Husband \\
P5 & 56 & Senior High School & Married 31 y & 3 children & Not working \\
P6 & 59 & Senior High School & Married 28 y & 3 children & Retired and works in a shop \\
\hline
\end{tabular}

There were six participants who live around Depok, West Java who participated in this research.

\section{The needs of elderly (In-depth interview results):}

1. Physical needs. These are needs including food, clothing, accommodation, health and spiritual needs. The health services needs are the most vital and important requirements. They need routine medication for their health, which are affordable or free and easy to obtain. Two out of six participants said:

"I hope the government can provide free medical treatment especially for my headache and some vitamins..." (P2)

"I hope there is a doctor where I live but I do not have enough money to pay the doctor and for medication, my money is enough only for food, I could not even buy new clothes ..." (her face looked sad and her eyes were full of tears) (P4).

2. Psychological needs. The psychological condition of elderly women is sensitive; they need an environment that understands their situation. Elderly women need friends who are able to empathize with their situation and understand their condition. They need friends that they can confide in, they need to be visited by their family, they need to be able to express their feelings and to be listened to. The elderly also need recreation, relaxation and opportunities to meet with their family and friends. Most of participants have feelings of loneliness and need fiends to talk to, for example:

"I always go to chat with my friends in the elderly community, they are all retired from the same oil company, and we share our previous experiences and have fun by chatting so that we feel not loneliness..." (P1)

"Every day I feel lonely at home, after I finish lunch and watch television, I feel bored and start thinking about walking out to meet my friend....." (P6).

"My children are growing and two of them are married and stay far from my house. My spouse passed away two years ago, now I live with my youngest son but he is very seldom at home, that it why I feel lonely and try to call my friends to chat together, but they all busy with their own family..."(P4)

3. Social needs. Social relationships are important especially among the elderly. It is important to have friends and a familiar community around them. They need to come together within the community for example religious activity, sport, 'arisan' and so on. Special needs also present themselves in cases where one spouse in a couple has recently passed away. They need someone that they can express their feelings to, so that they do not feel lonely, as stated by four out of six participants as follows:
"I always chat together among the elderly community every day, I cannot stay alone. Once per week my husband joins with the elderly community here who have sporting activities in the field close the Mosque. This gives me the chance to provide some snacks for them together with other women. Sometimes I join with the elderly women who participate in sport and exercise together under supervision from 'Posyandu' once a month. The 'Oil Retired Association' have a social meetings together twice per week. So I feel refreshed after I do those activities and feel healthier". (P1 and P5)

"We have two types of "arisan" each month which are organised by the neighborhood community and 'Bank retired community'; and we never miss it"(P4).

"I feel lonelier especially after my husband passed away, sometimes I feel frustrated and want to die to meet my husband..." (Her face full of tears) (P4).

4. Economical needs. For elderly women who do not have a source of income, they need financial support, mostly from their family. For the elderly who are still productive they need more skills and advice on how best to manage their financial sources to support their activities.

"I still have another son who is a University student, it needs money! ... that is why I earn money from this winkle (?) although I still got a pension. But it is not enough" (P6)

"All prices have increased now, but our salary is not increasing, so I need to work longer and get some money. I feel still strong enough to work, although my husband is reluctant to let me work again but we realize that we have to live ..." (P3)

5. Spiritual needs. The elderly mostly do a lot praying to pass their time. Through this activity they will feel safe and gain satisfaction in their lives. They would appreciate if the younger generation did more spiritual activities.

“Fortunately, we have a very active 'pengajian' (Muslim prayer group). We do it once every week and the venue is rotated among the neighbors" (P1, P6)

"We are close to the end of our life; we believe there is another life in another word, so we have to pray in order that Allah will bring us to the good place there...!" (P3, P5)

"If I feel loneliness and remember my late husband, then I will spend a lot of time praying, sometime I fall asleep when I pray" (P4).

"I try to encourage my children to pray when they are young so that they will pray for me when I am dead and they can have a good life" (P2).

6 . The elderly's expectation of their families, community 
and government services.

Most of the elderly expect that their family will provide care as a matter of course. They expect that their family still want to listen to elderly advice, and if there are differences, they will respond to their parents with a polite manner. The elderly hope that the next generation will still partake in religious activities, prayer, study hard, work hard, respect their values and culture, and follow their values so that they can have a better future.

There is an expectation on the community. All participants hoped that community would recognize that the elderly are still a valid part of the community. The community will pay due respect to the elderly and provide facilities for the elderly to partake in activities within the communities' life. The community should provide opportunities for the elderly to socialize and pass on their knowledge and life experiences. Communities should assist with providing finance to support elderly activities.

The expectations of the elderly on the government include in financing economic programs, providing social financial support, facilitate routine medical services that are easy to access and free at the point of use for the elderly. They hope that the government will initiate elderly programs throughout the country not only in the cities.

Service provision for elderly women based on kinship in Indonesia (Participants observations)

1. Physical services. The families provide food, at least three times a day, clothing which the elderly can still choose by themselves as well as some chosen by the family. The family provides suitable accommodation as best they can. For healthcare needs, the family takes them to the doctor and prepare simple medications in the home.

2. Psychological services. The services provided by the family usually involves the elderly person being accompanied by a family member who understands the psychology of the elderly. They understand that their behavior is strange and can be easily treated. The elderly can become childish, sensitive and uneasy.

3. Social services. Family try to talk with the elderly, listen their parents' advice, send news to the extended family, and inform them of contemporary events happening around them and also general news. Their grandchildren may bring them to meet their friends (other elderly persons) in their community.

4. Economic services. The economic services are provided by families to fulfill the needs of the elderly. If the elderly still retain the potential to work, they can work together with their families. For example most of the elderly women go to sell in their shop or sell food in front of their house along with their children or grandchildren. Most of the elderly women are happy if they can earn a small amount of money that they can use for their own needs or use to provide pocket money to their grandchildren. Most of participants prefer to prepare cooked food or snacks to be sold.

5. Spiritual services. The family provides the facility for prayer to their parents. They provide suitable surroundings and help them to pray as best as possible.

\section{Discussion}

Base on the results of the interviews and observations, it is clear that the needs of elderly align with the services provided by their families and communities. It is customary in Indonesian culture that the community and families look after the elderly and their parents until the end of their life. The findings of this study agree with the government's program to provide support services for the elderly as follows:

1. Services by government. The social services provided by the government has two systems, namely inside the institutional and non-institutional. Indonesia's government provides only a few nursing homes, (Panti wreda/Jompo) for the elderly, (mostly in the cities) with very limited services. The Indonesian social welfare system for the Elderly includes: $[2,3,4,5,6]$.

1) Services in the residence/nursing home (Panti Wreda/jompo). These are the basic institutional services. They provide accommodation, food, clothing, healthcare, recreational, social and spiritual support.

2) Geriatric wards in large hospitals especially for the ill elderly.

3) Services outside the institutions/home care: services managed by the community or community based services. These services encourage empowerment of the elderly based on a special project called Usaha Ekonomi Produktif (UEP) or productive economic activities, Bantuan Kelompok Usaha Bersama (KUBE) or the business groups working in the areas of poultry breeding, breeding other livestock (sheep, cattle etc), and nutritional support projects in all provinces $[3,4,5$, $6]$.

4) Health services for elderly called Posy Lansia, (community participation base).

2. Elderly services by the community. Communities provide social organization called 'Orsos'. They organize groups in the 'Karang Wredha', 'Karang Lansia group etc. Their activities support improvements in nutrition, sport, recreation, religious activities or prayer groups, cleaning together, herb growth and so on [2, 3, 4, 5]. Educationally, they provide classes to improve their skills for example in tailoring. They also have social activities to help the elderly who are terminally ill.

These results have shown that the needs of elderly are not only physical but also socio- and psychological. This has to be recognized by their family. This statement agrees with the study by Aumann et al (2008) which found that the majority, $(52 \%)$ of working caregivers in their study provide hands-on personal care every day or several times a week [1]. The health education provided by family nurses has to include this issue, and make the elderly's family aware of it. Additionally, it is important for the family to encourage their parents to participate in the programs provided by the government and the community.

\section{Nursing Implication}

The results of this study have shown that elderly women need physical, psychological, social and spiritual services. These have to be fulfilled jointly by health providers as well as their families. Nursing services especially gerontology nursing, family nursing and maternity nursing can use these results as a template via which to implement appropriate intervention to their clients, (the female elderly). Especially in Indonesia with 
many ethnic groups with their unique ethnic cultures, culturally sensitive nursing intervention is needed. The increasing population of elderly women and the issue of violence toward them must be considered in order to guide appropriate nursing intervention and thereby fulfill their physical, psychological, social, economic and spiritual needs.

\section{Conclusion}

Even though Indonesia still has a relatively small percentage of elderly, this population will increase. The Indonesian government have prepared with some programs to address this. Most of the elderly women in Indonesia stay at home and tend to spend their time with spiritual activities such as praying rather than physical and social activities because there are no specific facilities to ensure their safety and satisfaction. The need for services amongst the elderly especially women, are physical, psychological, social, spiritual and economic services. The study has shown the services for elderly women are based on kinship in Indonesia to address those needs. The study has also found that the elderly services provided by government and community align with the elderly's expectations of the community, government and their families. It is recommended for the family nurses, maternity nurses and gerontology nurses to encourage families and the elderly to participate in the government's and community's programs. A package of nursing intervention to fulfill the elderly women's' needs is recommended for further research.

\section{References}

[1] Aumann, K.; Sakai, K.; Brown, M.; Bond, J. T. (2008). The elderly care study: Everyday Reality and Wishes for Change. Families and Work institute. National Study of the Changing Workforce.

http://familiesandwork.org/site/research/reports/elder_care.pd $f$. Accessed at 28th January 2014.

[2] Departemen Sosial RI, 1996. Kelembagaan Lanjut Usia dalam Kehidupan Bangsa. Jakarta: Departemen Sosial RI.

[3] Departemen Sosial RI, 2003a. Pedoman Rencana Aksi untuk Kesejahteraan Lanjut Usia. Jakarta: Departemen Social RI.

[4] Departemen Sosial RI, 2003b. Pedoman Penyelenggaraan Pelayanan Sosial Lanjut Usia Berbasis Keluarga. Jakarta: DBPSLU.
[5] Departemen Sosial RI, 2004a. Standardisasi Pelayanan Sosial Lanjut Usia Luar Panti. Jakarta: DBPSLU.

[6] Departemen Sosial RI 2004b. Acuan Umum Perlindungan Sosial dan Aksesbilitas Lanjut Usia. Jakarta: DBPSLU.

[7] Departemen Sosial RI 2004c. Pedoman Penyiapan Pra Lanjut Usia dalam Memasuki Masa Tua. Jakarta: DBPSLU.

[8] Eliopoulos, C. (2005). Gerontological Nursing (2nd ed). Philadelphia: Lippincott Williams \& Wilkin.

[9] Gates D., Brehm B., Hutton S., Singler M., Poeppelman A., (2006). Changing the work environment to promote wellness: A focus group study. AAOHN Journal, 54 (12), 515-520.

[10] Kreager, P. (2003). Understanding Elderly Vulnerability in Indonesia, Elderly Care in Indonesia. IIAS_Newsletter NovNo. 32, page: 12 .

[11] Krueger R. A., Casey M. A. (2000). Focus groups: A practical guide for applied researchers (3rd ed.). Thousand Oaks, CA: Sage.

[12] Morgan D. L. (1988). Focus groups as qualitative research. Newbury Park, CA: Sage.

[13] Morgan D. L. (1996). Focus groups. Annual Review of Sociology, 22, 129-152. 10.1146/annurev.soc.22.1.129. Accessed at 28th January 2014.

[14] Sri Moertiningsih Adioetomo \& Lilis MCicih, (2009). Indonesia's Demographic Dividend and Ageing. The need for further research. Demographic Institute Faculty of Economics University of Indonesia. Presented in Symposium on Global Ageing and the Development of Education and Research in Gerontology - Geriatric, Depok, CHRUI, 3 June 2009

[15] Wisni Bantarti (2009). Global Ageing in Indonesia: Implications and Challenges from Social Welfare Perspective. Department of Social Welfare FISIP-UI.. presented in Symposium on Global Ageing and the Development of Education and Research in Gerontology - Geriatric, Depok, CHRUI, 3 June 2009.

[16] Sri Gati Setiti (2003). Pelayanan lanjut usia berbasis kekerabatan. Jakarta: Departemen Sosial RI.

[17] Sri Iswanti, dkk (2010). Pelatihan Kader untuk Menanggulangi Kekerasan terhadap Lansia Wanita. Yogjakarta: Lembaga Pengabdian Masyarakat Universitas Negeri Yogyakarta tahun 2010.

[18] Undang- Undang Republik Indonesia no. 13 tahun 1998. Kesejahteraan Lansia. 